\title{
Financial Repression, Financial Development and Structure of Savings in Pakistan
}

\author{
ASHFAQUE H. KHAN*
}

\section{INTRODUCTION}

The mobilization of domestic resources is one of the key determinants of sustained economic growth. Improving demestic resource mobilization involves raising the level of national savings to enable a higher level of investment, hence a faster rate of economic growth. Pakistan's saving performance and its overall economic performance appear to be incongruous. Over the past several years, Pakistan has maintained an economic growth of more than 6 percent which is laudable, but her performance with regard to savings has been poor. In fact, saving as a fraction of the Gross National Product (GNP) is one of the lowest among the developing countries. The current saving rate of about 14 percent of GNP fares badly with 23 percent for other low-income developing countries. ${ }^{1}$ What are the reasons for such a poor performance of savings in Pakistan? This paper attempts to provide some explanations for the causes of low savings in Pakistan.

In recent years, two schools of thought have emerged, namely the 'financial repressionist', ${ }^{2}$ and the 'financial structuralist' that have provided some insights into the causes of low savings, investment and growth in developing countries. The former, led by [McKinnon $(1973,1976)$ and Shaw (1973)], argues that the low (or negative) real interest rates caused by arbitrarily set ceilings on nominal interest rates and high and variable inflation rates are the major impediments to savings, financial deepening, capital formation and growth. The solution, therefore, lies in freeing the interest rates to find their equilibrium levels in a free market environment. The latter school of thought led by Goldsmith (1969) attributes the low savings, investment, and growth in developing countries to the relatively less developed financial structures in terms of financial assets, institutions, and markets. He states that a widespread network of financial institutions and a diversified array

*The author is Senior Research Economist at the Pakistan Institute of Development Economics, Islamabad. 1987

'See Government of Pakistan, Pakistan Economic Survey 1986-87, Ministry of Finance,

${ }^{2}$ Financial repression has been generally identified with low nominal interest rates and high and variable rates of inflation, or alternatively with the existence of negative real rates of interest. 
of financial instruments will have a beneficial effect on the saving-investment process and hence, on growth.

Keeping in view its importance for developing countries, considerable effort has been made to test empirically the model of financial repression developed by McKinnon and Shaw. ${ }^{3}$ All these studies have found considerable support for financial repression in developing countries. With respect to Pakistan, however, only [Abe et al. (1977) and Qureshi (1981)] have tested empirically the McKinnon-Shaw model and found that financial repression holds domestic saving below the level which would occur under a policy of financial liberalization.

In this paper besides empirically testing the viewpoints of two schools of thought mentioned above we also examine the impact of income (or permanent and transitory income), unanticipated inflation and price uncertainty on the savings behaviour in Pakistan covering a time period from 1959-60 to 1986-87. It has been argued in the literature [for example, see Gupta (1984)] that for the purpose of capital formation what is important is not only an increase in aggregate savings but also an increase in financial savings. It has also been recognized that aggregate savings may not be quite sensitive to changes in the real interest rate as compared with financial savings because of the possibility of substitution between financial savings and savings in physical assets. ${ }^{4}$ Thus, we also estimate a disaggregated saving function i.e. we divide the total savings (national savings) into financial savings and physical savings and examine the impact of various factors listed above on these two types of savings separately.

The plan of the paper is as follows. The methodology is discussed in Section II while the results are reported and discussed in Section III. The concluding remarks are contained in Section IV.

\section{METHODOLOGY}

To achieve the objectives of this study we use the following general model in line with Khan (1984) and Gupta (1984).

$$
S=\alpha_{0}+\alpha_{1} y_{p}+\alpha_{2} y_{T}+\alpha_{3} \dot{P}^{e}+\alpha_{4} \dot{P}^{u}+\alpha_{5} i+\alpha_{6} F_{r}+\alpha_{7} V_{E} \cdots
$$

where $S$ is savings (aggregate (or national)), financial, and physical savings.

$$
\begin{aligned}
& y_{p} \text { is real permanent income: } \\
& y_{T} \text { is real transitory income; }
\end{aligned}
$$

${ }^{3}$ For an extensive list of papers on this topic [see Gupta (1984); Eckaus (1977); Fry (1978, 1980, 1982); Galbis (1977, 1979); DeMelo and Tybout (1986) and Abe et al. (1977)] .

${ }^{4}$ See Gupta (1984). 
$\dot{P}^{e}$ is expected inflation;

$\dot{P}^{u}$ is unanticipated inflation;

$i$ is nominal return on deposits;

$F_{r}$ is financial intermediation ratio defined as $\mathrm{M}_{3} / \mathrm{GNP}$;

$M_{3}$ is the broadest definition of money; and

$V_{E}$ is inflation variability or price uncertainty.

Equation (1) can also be specified as

$$
S=\beta_{0}+\beta_{1} y_{r}+\beta_{2} y_{T}+\beta_{3} r+\beta_{4} \dot{P}^{u}+\beta_{5} F_{r}+\beta_{6} V_{E}
$$

where $r$ is the real return on deposits defined as

$$
r=i-\dot{P}^{e}
$$

For 'financial repressionist' view to be correct we would expect $\alpha_{3}<0$ and $\alpha_{5}>0$ and in the case of Equation (2) $\beta_{3}$ to be positive. ${ }^{5}$

It may be noted that five independent variables $\left(y_{P}, y_{T}, \dot{P}^{e}, \dot{P}^{u}\right.$ and $\left.V_{E}\right)$ in Equation (1) are unobservable and, therefore, they must be transformed into an observable form. We propose to overcome this problem by using three different expectations schemes - namely, perfect foresight, static expectations, and adaptive expectations. We assume that expectations are formed according to the adaptive expectations model.

$$
\begin{aligned}
& \dot{P}_{t}^{e}-\dot{P}_{t-1}^{e}=\theta\left(\dot{P}_{t}-\dot{P}_{t-1}^{e}\right) \\
& y_{t}^{p}-y_{t-1}^{p}=\lambda\left(y_{t}-y_{t-1}^{p}\right)
\end{aligned}
$$

where $\dot{P}_{t}^{e}$ represents the expected annual rate of inflation at time $t$ formed during the preceding year, $\dot{P}_{t}$ is the actual rate of inflation during the year $t$ and $\theta$ is the coefficient of expectations $(0 \leq \theta \leq 1)$. Similarly, $y_{t}^{p}$ and $y_{t}$ are respectively real permanent income and measured income at time $t$ and $\lambda$ is the coefficient of expectation $(0 \leq \lambda \leq)$. If $\theta=1$ and $\lambda=1$ then Equations (4) and (5) reduce to perfect foresight

$$
\dot{P}_{t}^{e}=\dot{P}_{t}
$$

${ }^{5}$ Details on theoretical justification of different variables included in Equations (1) and (2) are documented in Khan (1988) 


$$
y_{t}^{p}=y_{t}
$$

Similarly, if $\theta=0$ and $\lambda=0$ then Equations (4) and (5) reduce to static expectations

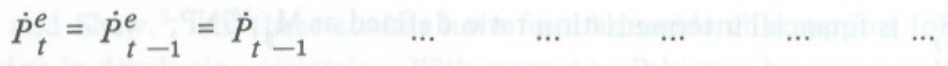

$$
\begin{aligned}
& \begin{array}{llllll}
y_{t}^{p}=y_{t-1}^{p}=y_{t-1} & \ldots & \ldots & \ldots & \ldots & \ldots
\end{array}
\end{aligned}
$$

i.e., expectations do not change from one period to the next. ${ }^{6}$ The variability of the rate of inflation is defined as

$$
V_{E}=\frac{1}{n} \sum_{i=0}^{n}\left[\left|\dot{P}_{t-i}-\dot{P}_{t-i-1}\right|\right]
$$

\section{RESULTS}

The results of Equation (2) under different expectations schemes corresponding to aggregate (or national), financial, and physical savings are reported in Tables 1, 2 and 3 respectively. ${ }^{7}$ Before we delve into the details, a few words regarding the weights of $\theta$ and $\lambda$ are in order. In order to construct series for expected inflation $\left(\dot{P}^{e}\right)$ and permanent income $\left(y_{p}\right)$ we needed the value of $\theta$ and $\lambda$. The optimal value of $\theta$ and $\lambda$ that minimizes the average loss from forecasting error in the quadratic-loss function is found to be $0.9 .^{8}$

\section{(a) Aggregate Savings}

The results corresponding to aggregate (or national) saving under different expectations schemes reported in Table 1 can be summarized as follows:

(i) that the marginal propensity to save (MPS) out of measured ( $y$ ) and permanent income $\left(y_{p}\right)$ under alternative expectations schemes are close to each other.

(ii) the MPS under different expectations schemes as well as under different sample periods range from 0.13 to 0.17 .

(iii) the strong hypothesis about the MPS from transitory income $\left(y_{T}\right)$ being unity is not confirmed under both static and adaptive expectations

${ }^{6}$ For detailed discussion on the choice of optimal weights for $\theta$ and $\lambda$, the method used to select the optimal weights and discussion on data, see Khan (1988).

${ }^{7}$ Because of the space limitation, the results are summarized here. For detailed discussion on the results along with the policy implications, see Khan (1988).

${ }^{8}$ For reasons as to why the optimal value of $\theta$ and $\lambda$ should be close to unity, see Khan schemes. However, the basic hypothesis that the MPS out of $y_{T}$ be greater than $y_{P}$ is confirmed.

Table 1

Estimates of National Savings under Alternative Expectations Schemes

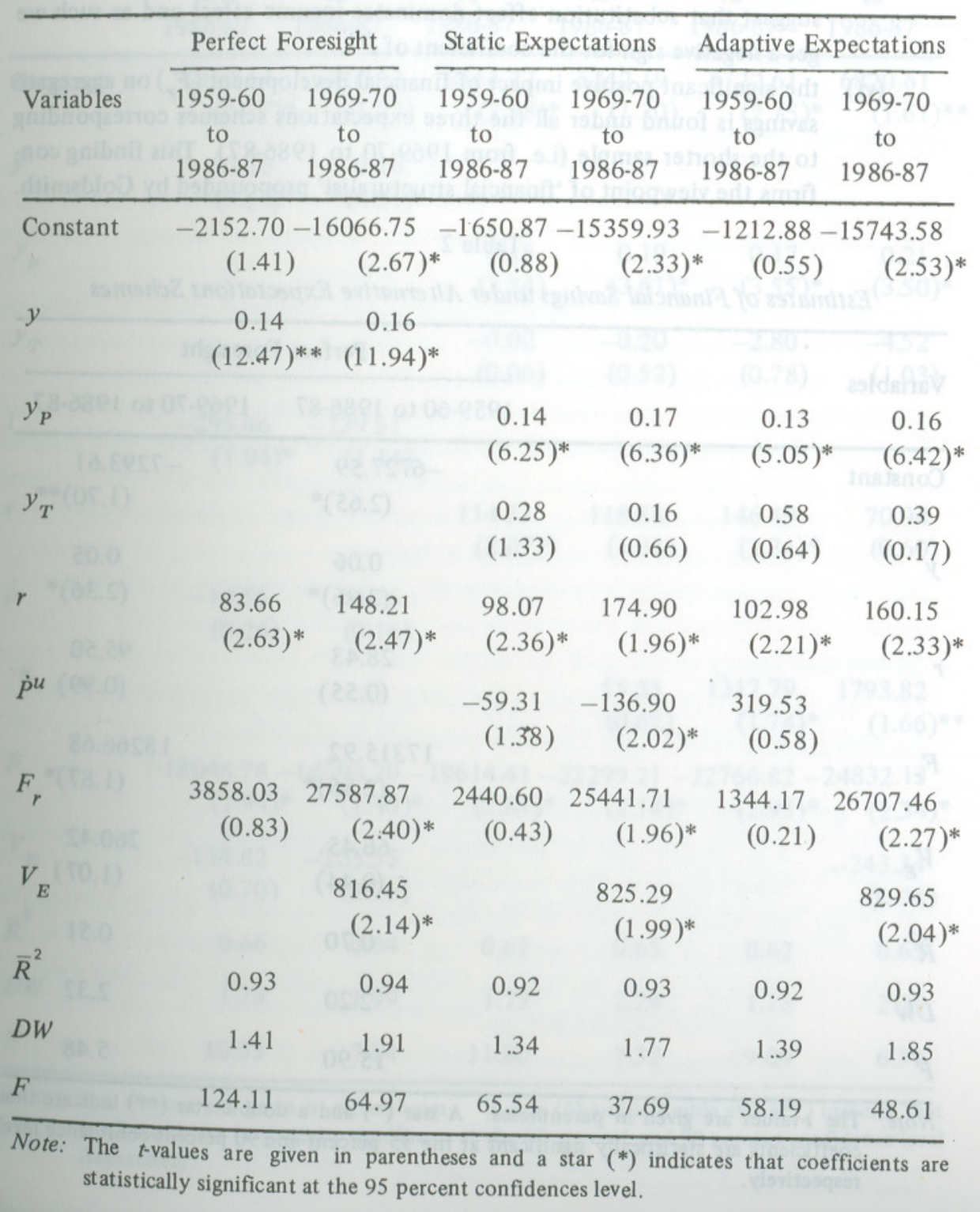


(iv) the positive and significant impact of real return on deposits on aggregate savings confirms the 'financial repressionist' hypothesis propounded by McKinnon and Shaw. The result indicates that an increase in real interest rate will stimulate aggregate savings in Pakistan.

(v) the unanticipated inflation is found to have a significant negative impact on aggregate savings in the case of static expectations only. This result suggest that substitution effect dominates income effect and as such we get a negative sign for the coefficient of $\dot{P}^{u}$.

(vi) the significant positive impact of financial development $\left(F_{r}\right)$ on aggregate savings is found under all the three expectations schemes corresponding to the shorter sample (i.e. from $1969-70$ to $1986-87$ ). This finding confirms the viewpoint of 'financial structuralist' propounded by Goldsmith

Table 2

Estimates of Financial Savings under Alternative Expectations Schemes

\begin{tabular}{|c|c|c|}
\hline \multirow{2}{*}{ Variables } & \multicolumn{2}{|c|}{ Perfect Foresight } \\
\hline & $1959-60$ to $1986-87$ & $1969-70$ to $1986-87$ \\
\hline Constant & $\begin{array}{r}-6727.59 \\
(2.65)^{*}\end{array}$ & $\begin{array}{r}-7293.61 \\
(1.70)^{* *}\end{array}$ \\
\hline$y$ & $\begin{array}{l}0.06 \\
(3.96)^{*}\end{array}$ & $\begin{array}{l}0.05 \\
(2.36)^{*}\end{array}$ \\
\hline$r$ & $\begin{array}{l}28.43 \\
(0.55)\end{array}$ & $\begin{array}{l}95.50 \\
(0.99)\end{array}$ \\
\hline$F_{r}$ & $\begin{array}{r}17315.92 \\
(2.55)^{*}\end{array}$ & $\begin{array}{r}18266.68 \\
(1.87)^{*}\end{array}$ \\
\hline$V_{E}$ & $\begin{array}{l}66.45 \\
(0.44)\end{array}$ & $\begin{array}{r}260.42 \\
(1.07)\end{array}$ \\
\hline $\bar{R}^{2}$ & 0.70 & 0.51 \\
\hline$D W$ & 2.20 & 2.32 \\
\hline$F$ & 15.90 & 5.48 \\
\hline
\end{tabular}

Note: The $t$-values are given in parentheses. A star $\left({ }^{*}\right)$ and a double star $\left({ }^{* *}\right)$ indicate that coefficients are statistically significant at the 95 percent and 90 percent confidence level respectively.
Table 3

Estimates of Physical Savings under Alternative Expectations Schemes

\begin{tabular}{|c|c|c|c|c|c|c|}
\hline \multirow[b]{2}{*}{ Variables } & \multicolumn{2}{|c|}{ Perfect Foresight } & \multicolumn{2}{|c|}{ Static Expectations } & \multicolumn{2}{|c|}{ Adaptive Expectations } \\
\hline & $\begin{array}{l}1959-60 \\
\text { to } \\
1986-87\end{array}$ & $\begin{array}{c}1969-70 \\
\text { to } \\
1986-87\end{array}$ & $\begin{array}{c}1959-60 \\
\text { to } \\
1986-87\end{array}$ & $\begin{array}{c}1969-70 \\
\text { to } \\
1986-87\end{array}$ & $\begin{array}{c}1959-60 \\
\text { to } \\
1986-87\end{array}$ & $\begin{array}{c}1969-70 \\
\text { to } \\
1986-87\end{array}$ \\
\hline Constant & $\begin{array}{l}6350.14 \\
\quad(2.77)^{*}\end{array}$ & $\begin{array}{r}5310.12 \\
(1.22)\end{array}$ & $\begin{array}{r}5566.27 \\
(2.58)^{*}\end{array}$ & $\begin{array}{r}5242.19 \\
\quad(1.30)\end{array}$ & $\begin{array}{c}6722.61 \\
(2.75)^{*}\end{array}$ & $\begin{array}{r}6820.61 \\
\quad(1.61)^{*}\end{array}$ \\
\hline$y$ & $\begin{array}{c}0.16 \\
(5.54)^{*}\end{array}$ & $\begin{array}{c}0.16 \\
(4.51)^{*}\end{array}$ & * & & & \\
\hline$y_{p}$ & & & $\begin{array}{c}0.15 \\
(3.84)\end{array}$ & $\begin{array}{l}0.19 \\
(3.61)^{*}\end{array}$ & $\begin{array}{c}0.17 \\
(3.55)^{*}\end{array}$ & $\begin{array}{l}0.21 \\
(3.50)^{*}\end{array}$ \\
\hline$y_{T}$ & $\sqrt{1}+2$ & 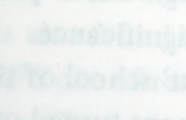 & $\begin{array}{c}-0.02 \\
(0.06)\end{array}$ & $\begin{array}{l}-0.20 \\
(0.52)\end{array}$ & $\begin{array}{c}-2.80 \\
(0.78)\end{array}$ & $\begin{array}{l}-4.52 \\
(1.03)\end{array}$ \\
\hline$i$ & $\begin{array}{r}-295.46 \\
(1.94)^{*}\end{array}$ & $\begin{array}{r}-239.51 \\
(1.14)\end{array}$ & & & & \\
\hline$r$ & r & 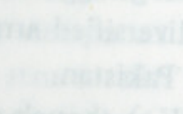 & $\begin{array}{c}114.51 \\
(2.07)^{*}\end{array}$ & $\begin{array}{r}118.58 \\
(1.32)\end{array}$ & $\begin{array}{c}146.49 \\
(2.31)^{*}\end{array}$ & $\begin{array}{l}70.94 \\
(0.60)\end{array}$ \\
\hline$\dot{p}$ & $\begin{array}{r}-14.56 \\
(0.26)\end{array}$ & $\begin{array}{l}16.76 \\
(0.16)\end{array}$ & & & & \\
\hline$\cdot u$ & & & & $\begin{array}{l}55.55 \\
(0.62)\end{array}$ & $\begin{array}{r}1317.79 \\
(1.74)^{*}\end{array}$ & $\begin{array}{r}1793.82 \\
(1.66)^{* *}\end{array}$ \\
\hline$F_{r}$ & $\begin{array}{c}-18048.74-1 \\
(2.94)^{*}\end{array}$ & $\begin{array}{c}16898.70-1 \\
(1.90)^{*}\end{array}$ & $\begin{array}{c}19614.41-2 \\
(2.87)^{*}\end{array}$ & $\begin{array}{c}22299.21-2 \\
(2.14)^{*}\end{array}$ & $\begin{array}{c}-22766.82-2 \\
(2.95)^{*}\end{array}$ & $\begin{array}{r}24832.13 \\
(2.34)^{*}\end{array}$ \\
\hline$V_{E}$ & $\begin{array}{r}-114.82 \\
(0.70)\end{array}$ & $\begin{array}{r}-205.55 \\
(0.76)\end{array}$ & & & & $\begin{array}{r}-243.34 \\
(0.94)\end{array}$ \\
\hline$D W$ & 0.66 & 0.64 & 0.62 & 0.65 & 0.62 & 0.65 \\
\hline$D W$ & 1.79 & 1.99 & 1.75 & 2.24 & 1.78 & 2.05 \\
\hline$F$ & 10.55 & 7.04 & 11.80 & 7.32 & 9.09 & 6.39 \\
\hline
\end{tabular}

Note: The $t$-values are given in parentheses. A star $\left({ }^{*}\right)$ and a double star $(* *)$ indicate that coefficients are statistically significant at the 95 percent and 90 percent confidence level respectively. 
Thus, in the case of Pakistan, the viewpoints of both schools of thought namely, financial repression, and 'financial structuralist' are firmly supported.

(vii) Inflation variability is found to have a significantly positive impact on aggregative savings under alternative expectations schemes with shorter sample period.

\section{(b) Financial Savings}

The results corresponding to financial savings are reported in Table 2 and are summarized as follows:

(i) the MPS out of measured income is found to vary between 0.05 to 0.06 suggesting that only 5 to 6 percent of additional income is saved in financial assets. ${ }^{9}$

(ii) the real return on deposits though has a positive coefficient, failed to reach the traditional level of significance. Thus, it provides limited support for 'financial repressionist' school of thought.

(iii) the variable of financial development turned out to be statistically significant with the expected positive sign, thereby supporting the viewpoint of 'financial structuralist'. This finding suggests that a widespread network of financial institutions and a diversified array of financial instruments will stimulate financial savings in Pakistan.

(iv) the uncertainty about inflation $\left(V_{E}\right)$, though positive was insignificant.

\section{(c) Physical Savings}

The results corresponding to physical savings under alternative expectations schemes are reported in Table 3 and can be summarized as follow:

(i) the MPS out of measured income is 0.16 while it ranges from 0.15 to 0.21 in the case of permanent income depending upon the type of expectations schemes and sample size.

(ii) the nominal return on deposits is found to have a significant negative impact on physical savings. This is quite consistent with the fact that as nominal return on deposits increases, people will substitute physical savings for financial savings.

(iii) the financial development variable $\left(F_{r}\right)$ is found to have a significant negative impact on physical savings. This suggests that as our financial

${ }^{9}$ The results corresponding to static as well as adaptive expectations model did not perform well and as such these are not reported in Table 2. sector develops in the sense that more and diversified array of financia instruments are available to the people, a shift will take place away from physical saving to financial savings.

(iv) as far as the impact of unanticipated inflation is concerned our finding suggest that it encourages the accumulation of physical assets.

\section{CONCLUSIONS}

The purpose of this paper has been to provide some explanations regarding the low level of savings in Pakistan in the light of recent theoretical development. It is found that a significant positive association exists between the real rate of return on deposits and aggregate savings. The interest elasticity of national savings ranges from 0.01 to 0.03 depending upon the choice of sample size. This suggests that given the existing real return on deposits (3.78) if increased by one percentage point then the increase in aggregate (or national) savings will range from 0.3 to 0.8 percent depending upon the choice of sample size. The aggregate real income (measured or permanent) is also found to be a key determinant of national, financial and physical savings. The MPS out of real income under various expectations schemes for three types of saving functions range from 0.06 to 0.21 . Financial development measured by the financial intermediation ratio is also found to have significant positive influence on national and financial savings while negative influence on physical savings. Thus, the viewpoints of two schools of thought, namely 'financial repressionist' and 'financial structuralist' are fully supported in the case of Pakistan.

Besides real income (measured or permanent) and real return on deposits there are other factors such as unanticipated inflation and variability of inflation which are found to have a significant impact on these saving functions. Finally, various expectations schemes were used to transform the unobservable variables into observable form. It is found that our results are not sensitive to the alternative expectations schemes.

These findings clearly point out the existence of financial repression on the one hand and lack of financial development on the other hand in Pakistan. The solution, therefore, lies in freeing the return on deposits to find their equilibrium levels in a free-market environment. In particular, the authorities should strive to make the ing inflation deposits positive either by increasing the nominal return or by reducing inflation. Furthermore, a widespread network of financial institutions and a diversified array of financial instruments will increase savings in Pakistan.

\section{REFERENCES}

Abe, S., M. J. Fry, B. K. Min, P. Vongipanond and T. Yu (1977). "Financial Liberalisation and Domestic Saving in Economic Development: An Empirical Test for 
Six Countries". Pakistan Development Review. Vol. XVI, No. 3.

DeMelo, J., and J. Tybout (1986). "The Effects of Financial Liberalization on Savings and Investment in Uruguay". Economic Development and Cultural Change. Vol. 34 , No. 3.

Eckaus, R. S. (1977). "A Program of Research on Finance and Development". Domestic Finance Studies No. 34, Development Economics Department, World Bank.

Fry, Maxwell J. (1978), "Money and Capital or Financial Deepening in Economic Development". Journal of Money, Credit and Banking. Vol. 10, No. 4.

Fry, Maxwell J. (1980). "Savings, Investment, Growth and the Cost of Financial Repression". World Development. Vol. 8, No. 4.

Fry, Maxwell J. (1982). "Models of Financially Repressed Developing Economies". World Development. Vol. 10, No. 9.

Galbis, Vicente (1977). "Financial Intermediation and Economic Growth in LessDeveloped Countries: A Theoretical Approach". Journal of Development Studies. Vol. 13, No. 2.

Galbis, Vicente (1979). "Money, Investment and Growth in Latin America, 19611973”. Economic Development and Cultural Change. Vol. 27, №. 3.

Goldsmith, R. W. (1969). Financial Structure and Development. New Haven: Yale University Press.

Gupta, K. L. (1984). Finance and Economic Growth in Developing Countries. London: Croom Helm.

Khan, Ashfaque H. (1982). "The Demand for Money and the Variability of the Rate of Inflation: An Empirical Note". Economics Letters. Vol. 10, Nos. 3-4.

Khan Ashfaque H. (1982a). "Permanent Income, Inflation Expectations and the Money Demand Function in Developing Countries". Pakistan Development Review. Vol. XXI, No. 4.

Khan, Ashfaque H. (1984). "Inflation, Its Variability and Consumption: Additional Evidence from Asian Countries". Submitted to Savings and Development.

Khan, Ashfaque H. (1988). "Financial Repression, Financial Development and the Structure of Savings in Pakistan". Paper Presented at the Fifth Annual General Meeting of Pakistan Society of Development Economists. Islamabad, January 4-6, 1989.

Khan, Ashfaque H. and Kalbe Abbas (1983). "Additional Evidence on Inflation Variability: The Experience of Asian Countries". Economics Letters, Vol. 12, No. 2 .

McKinnon, Ronald I. (1973). Money and Capital in Economic Development. Washington, D. C. The Brookings Institution.

McKinnon, Ronald I. (1976). Money and Finance in Economic Growth. New York: Marcel Dekker Inc.
Nugent, Jeffrey B., and C. Glezakos (1979). "A Model of Inflation and Expectations in Latin America". Journal of Development Economics. Vol. 6, No. 3.

Qureshi, Zia M. (1981). "Household Saving in Pakistan: Some Findings from TimeSeries Data". Pakistan Development Review. Vol. XX, No. 4.

Shaw, Edward S. (1973). Financial Deepening in Economic Development. New York: Oxford University Press. 


\section{Comments on \\ "Financial Repression, Financial Development and Structure of Savings in Pakistan"}

Dr Khan's paper is well written and addresses one of the chronic economic problems faced by Pakistan's economy or for that matter many other developing countries in the process of growth and development. The predicament is such that despite a steady respectable growth rate of 6.5 percent per annum, Pakistan's economy suffers from a low savings rate (14 percent as opposed to 23 percent for other developing countries) which consequently produces inadequate supplies of financial capital. This compels the policy-makers to unedertake foreign borrowing to meet the need for capital investment, thus pushing the economy into a highly indebted situation.

To substantiate his argument as to why the savings rate is so low in Pakistan, Dr Khan empirically tested two well-known theories in the areas of monetary economics of developing countries, namely: (a) Financial Repressionist (due to McKinnon and Shaw) which supports a more free competitive market for financial assets in order to raise the already very low (or negative) real rate of interest which in turn is expected to stimulate savings; (b) Financial Structuralist (due to Goldsmith) holds the lack of institutions and financial intermediation as the primary cause for low saving and thus suggests diversification of such financial institutions.

Although some work has been done before by Abe et al.and Qureshi to test these theories in the context of Pakistan, Dr Khan, however, has extended their work by incorporating some additional variables [e.g., permanent or transitory income, unanticipated inflation and price level] which I believe are very important and relevant. Not only that, he also estimated the two models on disaggregated savings data in order to capture the substitution between financial saving and savings in physical assets. This information should be very useful to the policy-makers in generating financial capital from a specific sector (i.e., from financial or physical assets).

Since, in my opinion, this study makes an important contribution to the literature, my comments will be focused to those issues which I believe can further strengthen Dr Khan's work.

(a) Instead of using the quadratic-loss function approach as suggested by Nugent and Glezakos which arbitrarily truncates the number of terms to three in Equations (10) and (11), one can use a Koyck transformation technique as given in [Pindyck and Rubin (1981) pp. 234-36]. The advantage of this technique is that it not only avoids the arbitrary truncation of the parameters, but it also allows for the recovery of all the crucial parameters.

(b) The use of perfect foresight to form expectations about the unanticipated price variable seems to be an extreme case wherein the agent is expected to make no systematic or random error. The real world situation may no provide so much information to the agent. I think one can effectively use rational expectations which simply states that the agent use all available information to form expectations and that, unlike perfect foresight, the agent can make unsystematic errors [to implement this method, se McCullum (1976) or Hasan (1987)]

M. Aynul Hasan

Acadia University,

Canada

\section{REFERENCES}

Hasan, M. A. (1987). "Rational Expectations Estimations of Macroeconometric Models: Some Monte Carlo Work”. Journal of Macroeconomics. 9, 297-315.

McCullum, B. (1976). "Rational Expectations and the Natural Rate Hypothesis: Some Consistent Estimates". Econometrica. 29; 315-35.

Pindyck, R. D. Rubinfeld (1981). Econometric Models and Economic Forecast. New York: McGraw-Hill, 